\title{
Leaf structure, microanalysis and characterization of the latex protein profile of Pachystroma longifolium (Nees) I.M. Jonhst. (Euphorbiaceae) in a seasonally dry Atlantic Forest
}

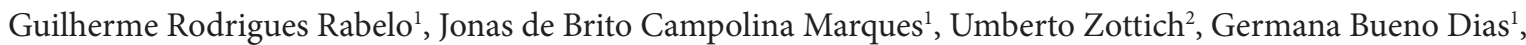 \\ Emílio Castro Miguel ${ }^{1}$, Valdirene Moreira Gomes² and Maura Da Cunha ${ }^{1,3}$
}

Recebido em 31/08/2010. Aceito em 17/01/2011

\begin{abstract}
RESUMO
(Estrutura foliar, microanálise e caracterização do perfil protéico do látex de Pachystroma longifolium (Nees) I.M. Jonhst. (Euphorbiaceae) em uma Floresta Atlântica semidecidual). Pachystroma longifolium é uma espécie perenifólia de Euphorbiaceae presente na floresta de tabuleiros, uma formação de floresta estacional semidecidual de terras baixas da Mata Atlântica. A área de estudo é um fragmento de floresta de tabuleiros com histórico de corte seletivo de madeira, na qual P. longifolium apresenta grande sucesso na colonização de áreas perturbadas em comparação com outras áreas mais preservadas dentro deste fragmento. No presente trabalho nós caracterizamos a estrutura foliar e látex de P. longifolium e sua importância como mecanismos de defesa contra dessecação e herbivoria a partir de diferentes técnicas de microscopia (microscopia eletrônica, microanálise e microscopia óptica) e bioquímicas. Nossos resultados sugerem que a riqueza de P. longifolium, nas áreas perturbadas do estudo, é primariamente em conseqüência de folhas impalatáveis devido à abundância de cristais de oxalato de cálcio no tecido parenquimático subjacente a epiderme; presença de compostos fenólicos na face adaxial da epiderme; um sistema laticífero contendo uma mistura de proteínas, a qual confere resistência aos herbívoros. Adicionalmente, esta espécie apresenta resistência à dessecação durante os períodos de seca devido a uma extensa camada lipídica na parede periclinal externa da epiderme, e a habilidade de reter água propiciada pela epiderme bisseriada.
\end{abstract}

Palavras-chave: estratégias anatômicas, cristais, cutícula, laticíferos, anatomia foliar

\begin{abstract}
(Leaf structure, microanalysis and characterization of the latex protein profile of Pachystroma longifolium (Nees) I.M. Jonhst. (Euphorbiaceae) in a seasonally dry Atlantic Forest). Pachystroma longifolium is an evergreen species of Euphorbiaceae that occurs in tabuleiro forest, a type of lowland Atlantic Forest. The site chosen for this study was a fragment of tabuleiro forest that has a history of being selectively logged for timber. P. longifolium is very successful at colonizing disturbed areas in this forest fragment in comparison with preserved fragments. In the present work, which was based on using different microscopy (electron and light microscopy, X-ray analysis) and biochemistry techniques, we describe the leaf and latex traits of $P$. longifolium and their role as defense mechanisms against desiccation and herbivory. Our results suggest the richness of $P$. longifolium populations, in the disturbed forest area studied, is primarily a consequence of unpalatable leaves because of an abundance of calcium oxalate crystals in the subjacent epidermis; the presence of phenolic compounds in the adaxial surface; and a laticifer system that contains a complex mixture of proteins, which provides resistance to herbivores. In addition, this species is resistant to desiccation during dry periods because of an extensive amount of wax that occurs on the outer cell walls of the epidermis, and its ability to retain water because of a biseriate epidermis.
\end{abstract}

Key words: anatomical strategies, crystals, cuticles, laticifers, leaf anatomy

1 Universidade Estadual do Norte Fluminense, Centro de Biociências e Biotecnologia, Setor de Biologia Vegetal, Laboratório de Biologia Celular e Tecidual, Goytacazes, RJ, Brazil

2 Universidade Estadual do Norte Fluminense, Centro de Biociências e Biotecnologia, Laboratório de Bioquímica e Fisiologia de Microrganismos, Goytacazes, RJ, Brazil

3 Author for correspondence: maurauenf@gmail.com 


\section{Introduction}

The Atlantic Forest of Brazil is considered the second most threatened ecosystem on Earth, and one of the five most important biodiversity hotspots (Myers et al. 2000). Today, this forest is fragmented and reduced to only $5 \%$ of its original area (Murray-Smith et al. 2009), and is mainly represented by two forest types, evergreen forest and lowland seasonal forest (Veloso et al. 1991).

The largest remnants of evergreen forest are on hilltops that are not ideal for farming, and deforestation is now occurring in the last remaining fragments of lowland seasonal forest (Dean 1996; Fundação SOS Mata Atlântica 1998) by humans that are illegally harvesting timber for commercial and domestic uses (Dean 1996; Villela et al. 2006). Besides the formation of gaps, this type of disturbance causes widespread damage to surrounding trees, subcanopy vegetation and soils (Curran et al. 2004).

The existence of light regimes (natural gaps and understory) and tolerant/intolerant shade species have been considered the most important aspects that explain the distribution of tree species in tropical and subtropical forests (Whitmore 1996). Selective logging alters the amount of incoming light in a forest, and many studies have reported changes in species composition in relation to this disturbance because it reduces the number of shade-tolerant species and stimulates species that demand light (Pélisser et al. 1998; Okuda et al. 2003).

According Coley et al. (1985), shade-tolerant species tend to have an increased number of defense mechanisms, such as unpalatable leaves, because their potential for tissue replacement is constrained by their low assimilation rate. On the other hand, faster-growing species, that demand more light, tend to be more susceptible to herbivores and expend more resources towards the replacement of tissue. In fact, herbivory can directly decrease the growth rate of the tropical understory (Marquis 1984; Sagers \& Coley 1995) and quantitative and qualitative changes in the leaf structure of plant species have been studied as an environmental indicator of this phenomenon (Dickison 2000).

The present study was performed in a fragment tabuleiro forest (a type of lowland Atlantic Forest) that has a history of being selectively logged. Within the study site, the evergreen tree Pachystroma longifolium (Nees) I.M. Jonhst. is distributed in gap and non-gap forest patches, but is at least three times commoner in gaps (Villela et al. 2006). Studies on floristic composition and forest dynamics of this fragment have been published (Silva \& Nascimento 2001; Nascimento \& Souza 2003). However, there is a lack of information on how the structural characteristics of leaves might help a plant population colonize gaps in this fragment and other forests.

This paper presents the results of an investigation about how leaf structural aspects and a latex protein profile might favor the establishment of $P$. longifolium in disturbed areas, within the largest fragment of a lowland forest on tertiary sediments in the state of Rio de Janeiro.

\section{Materials and methods}

\section{Sampling and study area}

Leaf samples of Pachystroma longifolium (Nees) I.M. Jonhst. were collected at the Guaxindiba Ecological Station, located in the São Francisco do Itabapoana district (21⒉' S, $41^{\circ} 04^{\prime}$ W) of northern Rio de Janeiro, Brazil. This is the largest fragment (ca. 1200 ha) of lowland forest on tertiary sediments in Brazil, which is known as tabuleiro Atlantic Forest (RadamBrasil 1983). This forest fragment has a history of disturbance mainly from logging for commercial timber species, charcoal production, and for plantation farming (Villela et al. 2006). Tabuleiro forest is classified, based on its phytogeographic features, as Seasonal Semideciduous Lowland Forest (Veloso et al. 1991). The climate can be classified as Aw, according to Köppen (1948), with an intense dry season from May to August (RadamBrasil 1983). Mean annual rainfall is approximately $1000 \mathrm{~mm}$; the wettest month is December and the driest is August (Villela et al. 2006). The mean annual temperature is $23{ }^{\circ} \mathrm{C}$ (RadamBrasil 1983). The soils are ultisols (USDA classification) and, according to Villela et al. (2006), the soils have low capacity for water retention and are poor in nutrients.

\section{Light microscopy}

Leaf fragments were fixed for two hours in a solution of $2.5 \%$ glutaraldehyde and $4.0 \%$ formaldehyde, buffered with $0.05 \mathrm{M}$ cacodylate, to $\mathrm{pH} 7.2$, at room temperature. After being rinsed with the same buffer, the samples were post-fixed with $1.0 \%$ osmium tetroxide in a $0.05 \mathrm{M}$ cacodylate buffer, at pH 7.2, for one hour. Subsequently, the samples were dehydrated in an ascendant series of acetone solutions. The material was infiltrated and embedded in epoxy resin (Polybed). Transverse sections of approximately $0.70 \mu \mathrm{m}$ were made and stained with a $0.1 \%$ toluidine blue aqueous solution (Johansen 1940). The slides were sealed with Entellan (Merck). Fragments of fresh leaf blades were clarified by dipping the samples in $2.5 \%$ sodium hypochlorite in order to observe the samples in paradermal view. Histochemical tests were carried out using free-hand sections of newly collected material, and included the ferric chloride test for phenolic compounds (Johansen 1940), the Ruthenium red test for carbohydrates (Johansen 1940), and the Sudan IV test for lipids (Johansen 1940). Crystals were tested by their insolubility in acetic acid and solubility in hydrochloric acid (McLean \& Cook 1958). Anatomical and histochemical descriptions were made with the aid of image analysis software (Axiovision') using an Axioplan Zeiss microscope. 


\section{Electron microscopy}

For scanning electron microscopy (SEM), the samples were fixed, post-fixed, dehydrated (as done for light microscopy) and rinsed in the same buffer. Afterwards, the samples were $\mathrm{CO}_{2}$ critical-point-dried (CPD 030 Baltec). Dried samples were adhered to stubs with carbon adhesive tape (3M) and sputter coated with $20 \mathrm{~nm}$ gold (SCD 050 Baltec). The material was observed using a ZEISS DSM962 microscope operating at $25 \mathrm{kV}$. For X-ray microanalysis newly collected material was fractured after freezing it in Nitrogen. Following this, the samples were critical-pointdried, and the dried samples were adhered to stubs with carbon adhesive tape and coated with carbon using a CED 030 Baltec. The qualitative analysis and the creation of the distribution map of the elements detected were performed using the same SEM, which was coupled to a silicium/lithium X-ray detector (OXFORD Microanalysis Group - Oxford, UK), with $138 \mathrm{eV}$ (1024 channels) nominal resolution, operating under standard conditions (voltage speed $25 \mathrm{KeV}$ [SE]; working distance of $25 \mathrm{~mm}$; capturing microanalysis time of 300 seconds with a Be window). Results were analyzed using the software LINKISIS (OXFORD Microanalysis Group - Oxford, UK). For transmission electron microscopy (TEM), the samples were fixed, post-fixed, dehydrated and embedded as described previously. The ultrathin sections $(70 \mathrm{~nm})$ were collected in copper grids (300 mesh), stained with acetate with 1.0\% uranyl, followed by $5.0 \%$ lead citrate. Sections were observed at $80 \mathrm{kV}$ using a ZEISS TEM 900 transmission electron microscope.

Extraction of latex proteins - Fresh latex $(1 \mathrm{~g})$ was ground into a fine powder and macerated in $\mathrm{N}_{2}$ liquid. Flour was defatted with petroleum ether (1:10) at room temperature for $1 \mathrm{~h}$. Peptides and proteins were extracted with a mixture of $1 \%(\mathrm{v} / \mathrm{v})$ trifluoroacetic acid (TFA), $1 \mathrm{M} \mathrm{HCl}, 5 \%(\mathrm{v} / \mathrm{v})$ formic acid, and $1 \%(\mathrm{w} / \mathrm{v}) \mathrm{NaCl}$ in the presence of pepstatin $\mathrm{A}(1 \mathrm{~g} / \mathrm{ml})$ at a seed/solvent ratio of 1:4 (Molina et al. 1997). Tris-Tricine/SDS gel electrophoresis was performed according to the method by Schagger \& Von Jagow (1987). The protein content of sample was determined as described by Bradford (1976).

\section{Results}

The leaf blade study of Pachystroma longifolium revealed a biseriate epidermis, covered with a well-developed cuticle layer (Fig. 1 and 2). The inner periclinal walls of the underlying adaxial surface are thicker than those of the epidermal walls of the first layer (Fig. 2). Striate cuticular ornamentation is observed only on the adaxial surface (Fig. 3). Crystals are observed in the underlying spongy parenchyma and palisade parenchyma (Fig. 2 and 4). The abaxial surface presents a single-layer covered with a thin cuticle layer (Fig. 4 and 5). In general, the dorsiventral mesophyll shows 1-2 cell layers of palisade parenchyma and 10-13 layers of spongy parenchyma (Fig. 1).

Paradermal sections of the clarified adaxial and abaxial surfaces revealed numerous prismatic oxalate crystals identified by their insolubility in acetic acid and solubility in hydrochloric acid (Fig. 6 and 7; note the crystal accumulating along the veins of the leaf). Anomocytic stomata are observed only on the abaxial surfaces (Fig. 8). The qualitative analysis of the chemical elements that constitute the crystals revealed a predominance of calcium (Fig. 9). The map of the distribution of calcium shown using Speed Map ${ }^{\circ}$ (Fig. 10) coincided with the location of the crystals (Fig. 11).

Presence of phenols is only observed in the adaxial surface (Fig. 12). The Sudan IV test revealed that both surfaces have a thick lipid portion in the outer cell wall, which extended up to the anticlinal cell wall (Fig. 13 and 14). In contrast, the Ruthenium red test only showed the presence of polysaccharides and pectin (Fig. 15 and 16) in the underlying adaxial epidermal walls. This test also contributed to revealing the lipids within both surfaces, which were not stained by the Ruthenium red.

In the transmission electronic microscopy, the outer periclinal cell walls of the adaxial surface presents three distinct layers: a thin cuticle proper layer; a thicker cuticular membrane, with a reticulated and tree-like network that is polysaccharide-rich; and an inner polysaccharide-rich layer (Fig. 17 and 18). The cuticular membrane has a slightly reticulated network and, in comparison with the inner polysaccharide-rich layer, it has a thin inner polysaccharide layer. The presence of laticifers immersed in the cuticular membrane is remarkable, and forms an electron-dense matrix that surrounded the laticifer (Fig. 18 and 19), which might be polysaccharide-rich. Laticifers are also observed in adaxial surface and between the underlying epidermis and the palisade parenchyma (Fig. 20 and 21; note the thick inner periclinal wall of the sub-epidermal layer in figure 22). In these two situations, the laticifers shows a thicker cell wall compared to those of adjacent cells, and two noticeable cell wall layers, an inner electron-lucent layer and an outer electron-dense layer.

The laticifers are articulated and unbranched (Fig. 23). The presence of proteins in the latex of P. longifolium was also examined. Crude and dialyzed extracted latex preparations that were analyzed using Tris-Tricine/SDS gel electrophoresis under reducing conditions (Fig. 24). The results of this analysis suggest that the latex of $P$. longifolium is a complex mixture of proteins with molecular masses that range from approximately $14 \mathrm{kDa}$ to over $16.95 \mathrm{kDa}$.

\section{Discussion}

This study was done in a forest with a history of disturbance, mostly from selective logging, where P. longifolium exhibited the ability to colonize disturbed areas, where there were three 

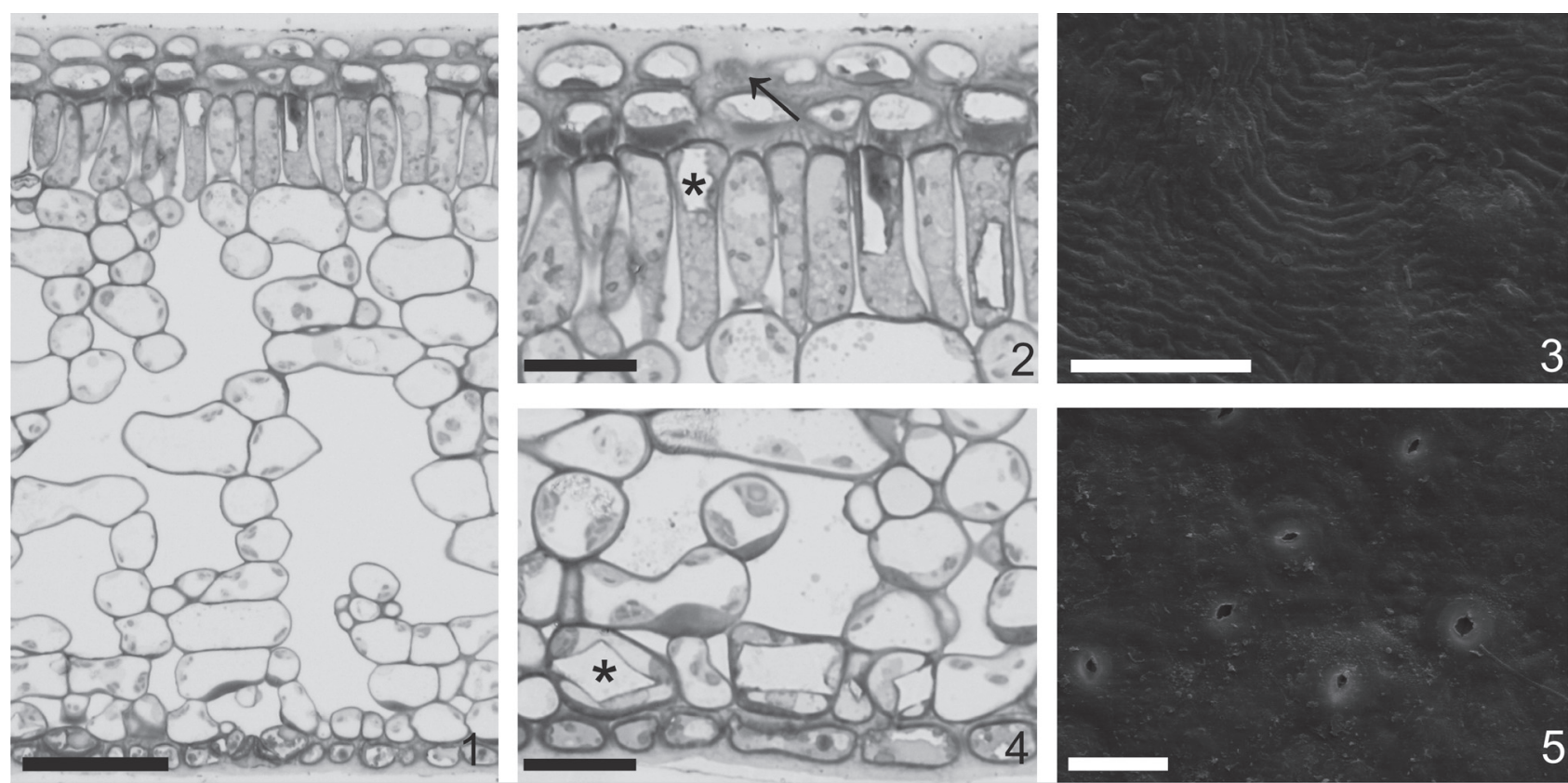

Figures 1-5. Leaf anatomy and micromorphology of Pachystroma longifolium (Nees) I.M. Jonhst. 1. Transversal section of leaf blade showing dorsiventral mesophyll. 2. Transversal section of adaxial face epidermis and palisade parenchyma. Note the well-developed cuticle layer (closed arrow) and the presence of crystals (asterisks). 3. Adaxial surface micrograph showing the striate cuticular ornamentation. 4. Transversal section of abaxial face epidermis, note the abundance of crystals (asterisks) in the mesophyll. 5. The non-ornamented cuticle of abaxial surface. Scale bar: $1=50 \mu \mathrm{m} ; 2-5=20 \mu \mathrm{m}$.

times as many individuals of this species compared to preserved areas (Villela et al. 2006). In the present work we suggest that the richness of $P$. longifolium populations, in the disturbed areas, might be because of two anatomical strategies. First, this species has unpalatable leaves, which provides resistance to herbivores, because of an abundance of calcium oxalate crystals, phenolic compounds in adaxial surface, and a laticifer system. Second, this species is resistant to desiccation during dry periods because its leaves have extensive amounts of wax on the outer cell walls and it has the ability to retain water because of a multiple epidermis.

According to Franceschi \& Nakata (2005), numerous hypotheses about the functions of crystals (for calcium regulation, plant defense and detoxification) are based on the diversity of crystal shapes and sizes, and their prevalence and spatial distribution. The high concentration of Ca in the forest soil at the study site (Villela et al. 2006) supports the calcium regulation hypothesis, a mechanism for regulating bulk $\mathrm{Ca}$ levels in plant tissues and organs that grow in environments where soluble $\mathrm{Ca}$ is abundant (Volk et al. 2002; Franceschi \& Nakata 2005). The physical nature of the crystals and their relative abundance, which makes the leaves of $P$. longifolium unpalatable, would create a mechanical defense against herbivores (Franceschi \& Loewus 1995; Franceschi 2001; Hudgins et al. 2003; Franceschi \& Nakata 2005). Crystal accumulation occurs along the veins because the site of entry of $\mathrm{Ca}$ is the xylem. Consequently, precipitation in the cells surrounding the veins will prevent the $\mathrm{Ca}$ from accumulating around the chlorenchyma cells, which could affect cellular function (Macnish et al. 2003).
Phenolic compounds are a huge group of multifunctional carbon-based secondary metabolites that are mainly synthesized from cinnamic acid produced by the shikimate pathway (primary) and the secondary (phenylopropanoid) metabolism (Dixon \& Paiva 1995). A phenolic metabolism in plants can be induced by certain environmental factors, such as stress, injury or infection, and can protect a plant from insectivores (Rees \& Harborne 1985; Dixon \& Paiva 1995; Takahama \& Oniki 2000; Da Cunha et al. 2010). Most of these phenolic compounds have antimicrobial, antifeedant and antifungal activity that create a defense mechanism against herbivores and microorganisms (Beckman 2000; Wititsuwannakul et al. 2002; Eichhorn et al. 2007). The phenolic compounds, observed only in the double-layered of the adaxial surface epidermis, are probably part of the chemical defense system that helps $P$. longifolium resist pathogens and herbivorous.

Although there is no constant relationship between cuticle thickness and water permeability, because thicker cuticles can even have higher permeabilities (Becker et al. 1986). It is known that plant cuticular permeability has contributed to minimizing uncontrolled water loss when the stomata are closed since the earliest terrestrial plants emerged (Becker $e t$ al. 1986; Edwards et al. 1996; Kerstiens 1996).

Cuticular waxes form the main barrier to the diffusion of water and solutes across the cuticle (Schreiber \& Riederer, 1996; Buchholz et al. 1998; Buchholz \& Schönherr 2000; Jäger et al. 2010). However, Schönherr \& Riederer (1989) remarked that the main diffusion barrier is located in a relatively narrow band at or near the outer surface of the cuticular membrane, which they called the limiting skin. 

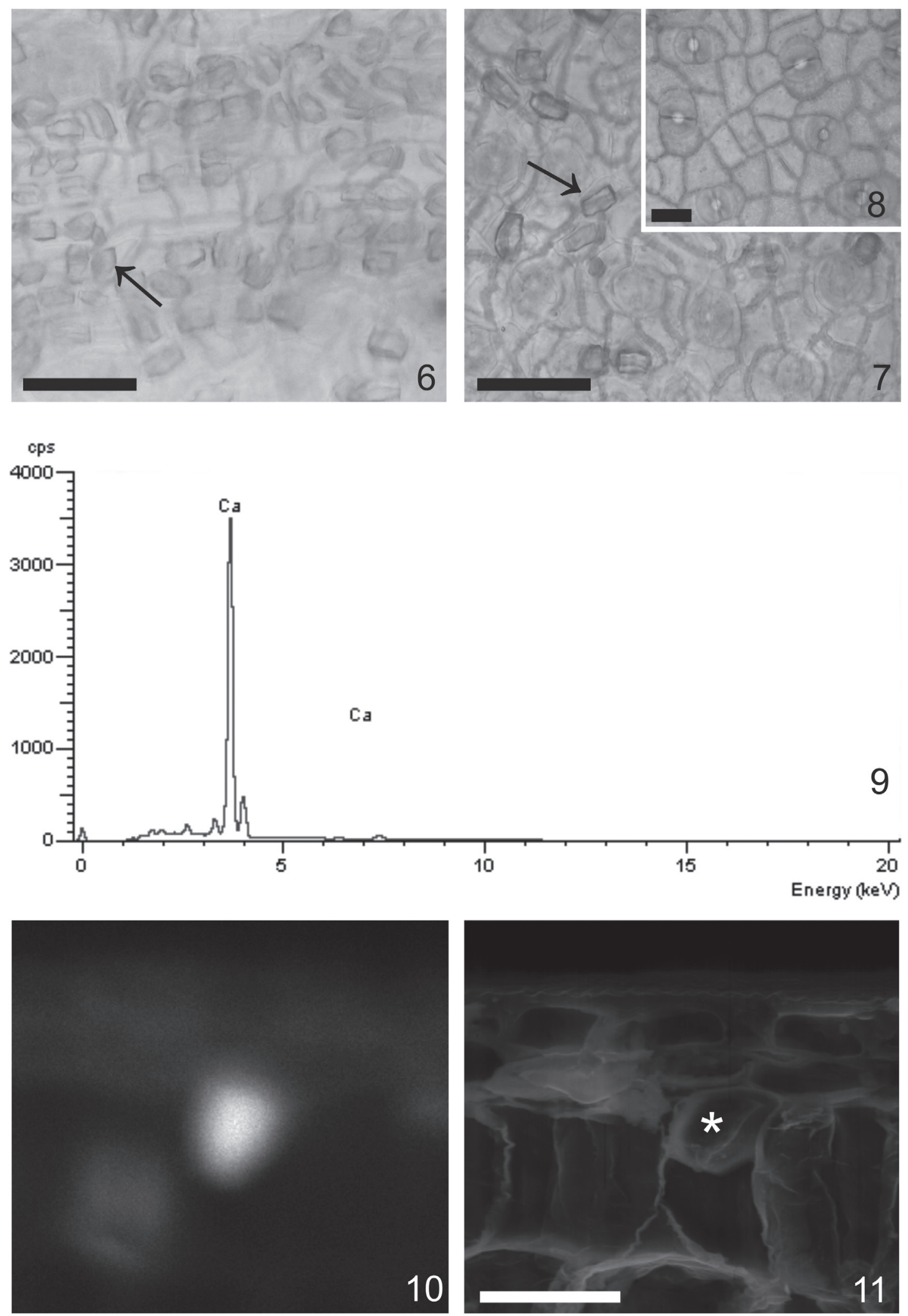

Figures 6-11. Paradermic sections of the clarified adaxial and abaxial surfaces and microanalysis of an X-ray of the crystals of Pachystroma longifolium (Nees) I.M. Jonhst. 6. Adaxial surface of epidermis with numerous prismatic oxalate crystals. Note the crystals accumulating along the veins of the leaf (closed arrow). 7. Abaxial surface of epidermis with numerous oxalate crystals (closed arrow). 8. Detail of anomocytic stomata. 9. Qualitative analysis of the constitution of the chemical elements of the crystals. 10. Speed Map showing where calcium is present in the former image. 11. SEM micrograph of prismatic crystal in palisade parenchyma (asterisks). Scale bar: 6-7 $=50 \mu \mathrm{m} ; 8=25 \mu \mathrm{m}, 10$ and $11=20 \mu \mathrm{m}$. 

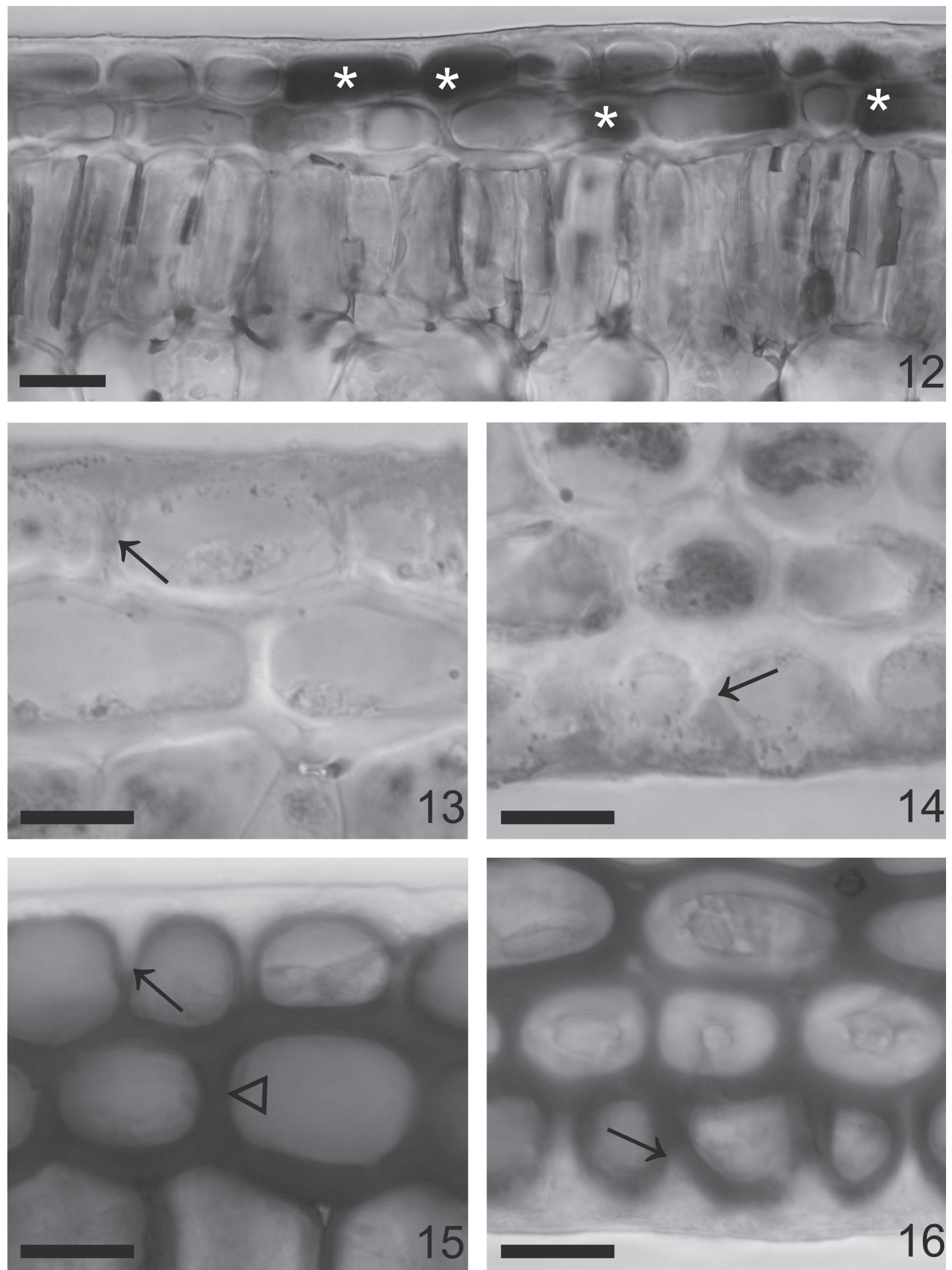

Figures 12-16. Histochemical tests in the transverse section of leaf blade of Pachystroma longifolium (Nees) I.M. Jonhst. 12. Ferric chloride test showing the presence of phenols in the adaxial surface of epidermis (asterisks). 13-14. Sudan IV test that revealed a thick lipid portion in the outer cell wall which prolonged (closed arrow) until the anticlinal cell wall to the lipids in the adaxial and abaxial surface. 15-16. Ruthenium red test showing the pectic nature of the underlying adaxial surface of epidermis (open triangle). This test also helps to exhibit the anticlinal cell wall extension of the lipid portion in the adaxial and abaxial surfaces (closed arrow). Scale bar: $12=20 \mu \mathrm{m} ; 13-16=10 \mu \mathrm{m}$. 

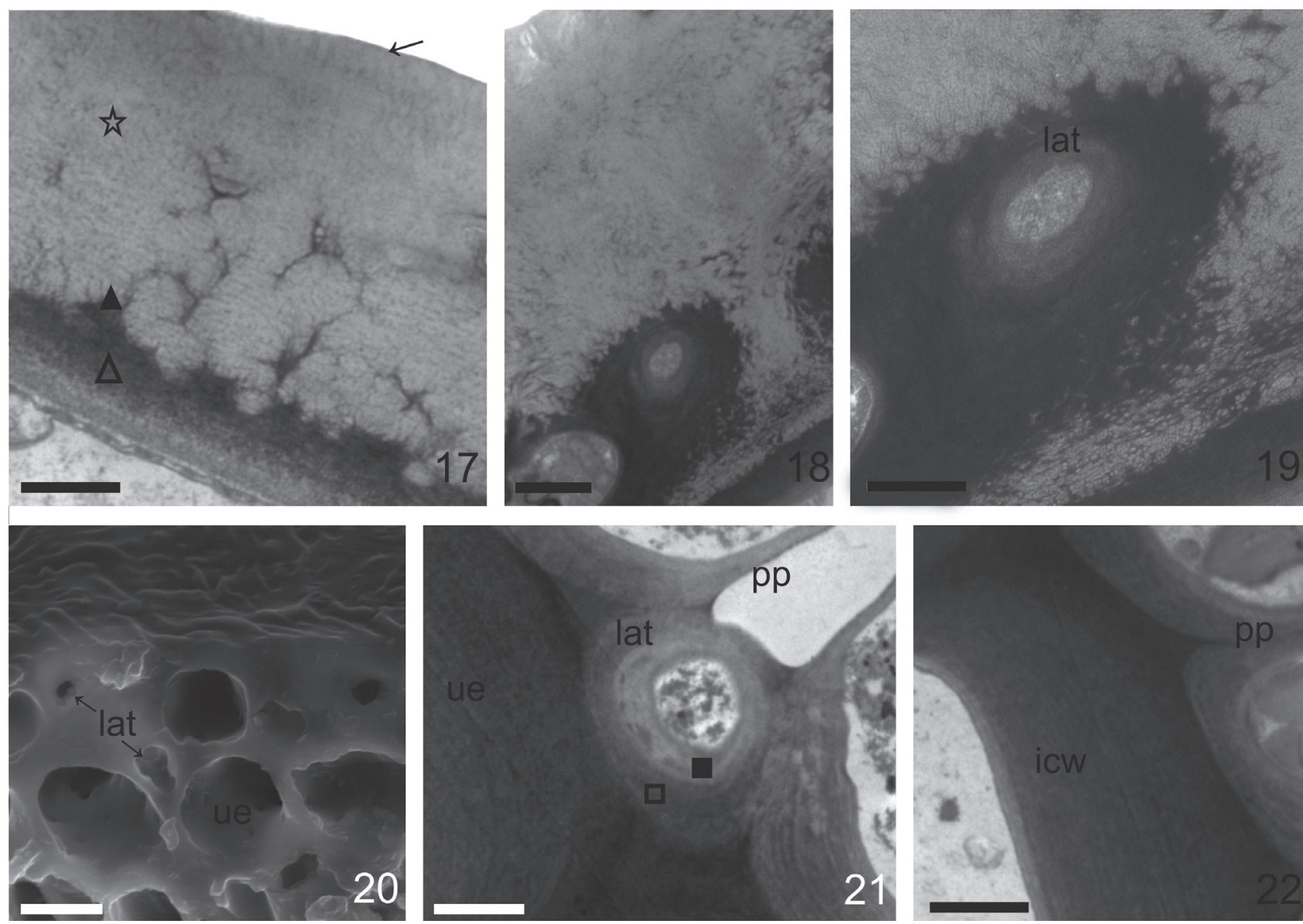

Figure 17-22. Transmission electron microscopy (TEM) and scanning electron microscopy (SEM) micrographs in transverse sections of Pachystroma longifolium (Nees) I.M. Jonhst. leaves. 17. The outer cell wall of adaxial surface, with a cuticle proper layer (closed arrow); a thicker cuticular membrane with a reticulated (open star) and tree-like network (closed triangle); a thin inner polysaccharide layer (open triangle). 18-19. Laticifers (lat) immersed in a cuticular membrane, forming an electron-dense matrix-surrounding the laticifer, which is possibly polysaccharide-rich. 20. SEM micrograph of a leaf cross section. Note the laticifers (lat) in adaxial surface and between the adaxial and the underlying sub-epidermal surface. 21. Laticifers between the underlying sub-epidermal epidermis (ue) and the palisade parenchyma (pp) showing a thicker cell wall with two noticeable layers, an inner electron-lucent (closed square) layer and an outer electron-dense layer (open square). 22. The thick inner periclinal wall of the sub-epidermal layer (icw). Scale bar: $17-18=2 \mu \mathrm{m} ; 19=100 \mathrm{~nm} ; 20=10 \mu \mathrm{m} ; 21-22=500 \mathrm{~nm}$.

In fact, small, polar but uncharged water molecules diffusing across the cuticle usually move via the lipophilic pathway, dissolved in the amorphous phase of the cuticular wax, while a minor fraction of the water may diffuse through polar pores of molecular dimensions (Riederer \& Schreiber 2001). Although cuticle composition, organization and proportion of wax can vary, the extent of the amorphous phase that is characterized by the lipophilic wax matrix is probably the main barrier to water diffusion (Tenberge 1992); except in the case of moist environments, where the cuticle swells because of water absorption, which in turn leads to an increase in cuticular transpiration (Schreiber et al. 2001). In the semideciduous forest studied, which has a notable dry season, the thick cuticles of the evergreen $P$. longifolium have an extensive amount of wax (observed by TEM and histochemical tests) that could promote resistance to desiccation during dry periods while the underlying adaxial surface of epidermis promotes water storage in the leaf tissues because of the pectic nature of the walls (Kaul 1977; Takemori et al. 2003).

The description of the articulated and unbranched laticifers of $P$. longifolium differs from other Euphorbiaceae, such as Euphorbia and Chamaesyce that are characterized by the presence of non-articulated laticifers (Mahlberg 1993; Da Cunha et al. 1998). Da Cunha et al. (1998) reported, in Chamaesyce, a thicker laticifer cell wall that had a higher quantity of pectic substances than the walls of adjacent cells. The two conspicuous laticifer cell wall layers of $P$. longifolium are indicative of their different composition, which are possibly comprised of an outer electron-dense layer, representing a polysaccharide-rich layer, and an inner electron-lucent layer, representing a primary cell wall. Although laticifers occur in many different plant organs and tissues (Metcalfe \& Chalk 1988; Fahn 1990), their occurrence among epidermal cells highlights the constitutive defense of $P$. longifolium, where an injury to a leaf causes latex to promptly exude from the damaged area. 

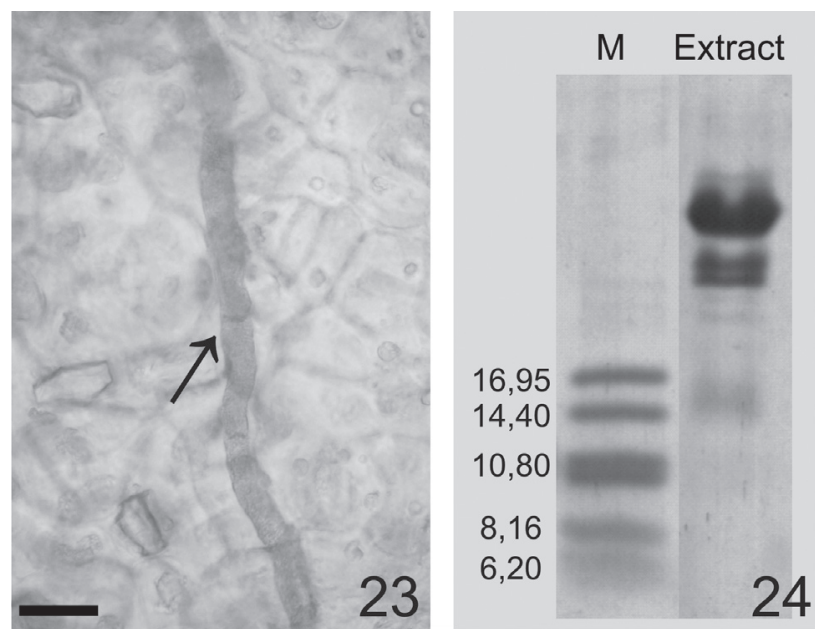

Figures 23-24. Paradermic sections of Pachystroma longifolium (Nees) I.M. Jonhst. leaves and gel electrophoresis. 23. Clarified adaxial surface. Note the articulated and unbranched laticifers (closed arrow). 24. SDS-polyacrylamide gel electrophoresis of proteins from P. longifolium latex. M, markers (kDa). Scale bar: $23=20 \mu \mathrm{m}$.

The physical and chemical characteristics of the latex produced by certain plants can act as a defense against insects and other pathogens, and many types of latex are known to have high concentrations of enzymes (Giordani et al. 1991; Giordani \& Lafon 1993). Latex contains a diversity of biologically active compounds that provide resistance to herbivores via toxicity or anti-nutritive and mechanical effects. The two major defense-related components in latexes are secondary metabolites (terpenoids, alkaloids, etc.) and different protein classes (Agrawal \& Konno 2009). Various latexes are known to contain glycosidases (Giordani \& Lafon 1993), proteases (Kimmel \& Smith 1954; Sgarbieri et al. 1964; Lynn \& Clevette-Radford 1987b; Arribére et al. 1998; Arima et al. 2000; Tomar et al. 2008), acid phosphatases (Lynn \& Clevette-Radford 1987a), amylases (Lynn \& Clevette-Radford 1987a), chitinases (Jekel et al. 1991), hevein (Van Parijs et al. 1991), proteinase inhibitors (Archer 1983; Lin \& Lu 1994), b-1,3-glucanase (Chye \& Cheung 1995) and various other enzymatic activities (Lynn \& Clevette-Radford 1987b; Agrawal \& Konno 2009).

The results of this study also suggest that proteins responsible for the observed effects may potentially be utilized as insecticides or fungicides by manipulating of their genes and incorporating them into agriculturally important plants.

This study describes the leaf and latex traits of $P$. longifolium, and their role as defense mechanisms against desiccation and pathogens that help promote the richness of $P$. longifolium populations in disturbed forest areas. Based on studies using different microscopy (TEM, SEM, X-ray analysis and light microscopy) and biochemistry techniques we suggest that the desiccation resistance of $P$. longifolium is promoted by extensive amounts of wax on the outer cell walls of its leaves, its ability to retain water because it has a biseriate epidermis, and its defense mechanism against pathogens because of unpalatable leaves caused by the abundance of calcium oxalate crystals, the presence of phenolic compounds in epidermis, and the complex mixture of proteins present in its latex. Further studies are necessary to determine if the activity of these proteins is a plant defense mechanism.

\section{Acknowledgements}

The authors are indebted to Conselho Nacional de Desenvolvimento Científico e Tecnológico (CNPq), Fundação de Amparo a Pesquisa do Rio de Janeiro (FAPERJ), Coordenação de Aperfeiçoando de Pessoal de Nível Superior (CAPES) for their financial support. We thank the technicians Beatriz Ferreira Ribeiro and Giovanna Alves de Moraes of Laboratório de Biologia Celular e Tecidual da Universidade Estadual do Norte Fluminense (LBCT/UENF) for helping with laboratory tasks, and the Instituto Estadual do Ambiente (INEA) to the plant collecting license. This study was part of the $\mathrm{PhD}$ thesis of the first author, presented to the Programa de PósGraduação em Biociências e Biotecnologia da Universidade Estadual do Norte Fluminense (UENF).

\section{References}

Agrawal, A.A. \& Konno, K. 2009. Latex: a model for understanding mechanisms, ecology, and evolution of plant defense against herbivory. Annual Review of Ecology, Evolution and Systematics 40: 311-331.

Archer, B.L. 1983. An alkaline protease inhibitor from Hevea brasiliensis latex. Phytochemistry 23: 633-639.

Arima, K.; Uchikoba, T.; Yonezawa, H.; Shimada, M. \& Kaneda, M. 2000. Cucumisin-like protease from the latex of Euphorbia supina. Phytochemistry 53: 639-644.

Arribére, M.C.; Cortadi, A.A.; Gattuso, M.A.; Bettiol, M.P. \& Priolo, N.S. 1998. Comparison of Asclepiadaceae latex proteases and characterization of Morrenia brachystephana Griseb. cysteine peptidases. Phytochemistry Analytical 9: 267-273.

Becker, M.; Kerstiens, G. \& Schönherr, J. 1986. Water permeability of plant cuticles: Permeance, diffusion and partition coefficients. Trees 1: 54-60.

Beckman, C.H. 2000. Phenolic-storing cells: keys to programmed cell death and periderm formation in wilt disease resistance and in general defence responses in plants? Physiological and Molecular Plant Pathology 57: 101-110.

Bradford, M.M. 1976. A rapid and sensitive method for the quantification of microgram quantities of protein utilizing the principle of dye binding. Biochemistry 72: 248-254.

Buchholz, A.; Baur, P. \& Schönherr, J. 1998. Differences among plant species in cuticular permeabilities and solute mobilities are not caused by differential size selectivities. Planta 206: 322-328.

Buchholz, A. \& Schönherr, J. 2000. Thermodynamic analysis of diffusion of non-electrolytes across plant cuticles in the presence and absence of the plasticiser tributyl phosphate. Planta 212: 103-111.

Chye, M.L. \& Cheung, K.Y. 1995. B-1,3-glucanase is highly-expressed in laticifers of Hevea brasiliensis. Plant Molecular Biology 29: 397-402.

Coley, P.D.; Bryant, J.P. \& Chapin, F.S. 1985. Resource availability and plant antiherbivore defense. Science 230: 895-899.

Curran, L.M.; Trigg, S.N.; McDonald, A.K.; Astiani, D.; Hardiono, Y.M.; Siregar, P.; Caniago, I. \& Kasischke, E. 2004. Lowland forest loss in protected areas of Indonesian Borneo. Science 303: 1000-1003.

Da Cunha, M.; Costa, C.G.; Machado, R.D. \& Miguens, F.C. 1998. Distribuition and differentiation of the laticifer system in Chamaesyce 
thymifolia L. Millsp. (Euphorbiaceae). Acta Botanica Neerlandica 472: 209-218.

Da Cunha, M.; Grativol, D.K.; Filho, I.V.B.; Magalhães, J.A.S.; Gomes, V.M.; Souza, W.; Moura, J.I.L.; Bezerra, J.L. \& Miguens, F.C. 2010. Fine structure of phloematic trypanosomatid coconut tree interaction. Journal of General Plant Pathology 76: 74-83.

Dean, W. 1996. A ferro e fogo: a história e a devastação da Mata Atlântica brasileira. São Paulo, Companhia das Letras.

Dickison, W.C. 2000. Integrative plant anatomy. San Diego, Harcourt Academic Press.

Dixon, R.A. \& Paiva, N.L. 1995. Stress-induced phenylpropanoid metabolism. The Plant Cell 7: 1085-1097.

Edwards, D.; Abbott, G.D. \& Raven, J.A. 1996. Cuticles of early land plants: a palaeoecophsiological evaluation. Pp. 1-32. In: Kerstiens, G. (Ed.). Plant cuticles: an integrated functional approach. Oxford, Bios Scientific Publishers..

Eichhorn, M.P.; Fagan, K.C. \& Compton, S.G. 2007. Explaining leaf herbivory rates on tree seedlings in a Malaysian Rain Forest. Biotropica 393: 416-421.

Fahn, A. 1990. Plant anatomy. Oxford, Pergamon Press.

Franceschi, V.R. \& Loewus, F.A. 1995. Oxalate biosynthesis and function in plants and fungi. Pp. 113-30. In: Khan, S.R. (Ed.). Calcium Oxalate in Biological Systems. Boca Raton, CRC.

Franceschi, V.R. 2001. Calcium oxalate in plants. Trends in Plant Science 6: 331 .

Franceschi, V.R. \& Nakata, P.A. 2005. Calcium oxalate in plants: Formation and fuction. Annual Review of Plant Biology 56: 41-71.

Fundação SOS Mata Atlântica 1998. Atlas da evolução dos remanescentes florestais e ecossistemas associados no domínio da Mata Atlântica no período 1990-1995. São Paulo, Fundação SOS Mata Atlântica.

Giordani, R.; Moulin, A. \& Verger, R. 1991. Tributyroylglycerol hydrolase activity in Carica papaya and other latices. Phytochemistry 30: 1069-1072.

Giordani, R. \& Lafon, L. 1993. Action of Carica papaya latex on cell wall glycosidases from Lactuca sativa. Phytochemistry 34: 1473-1475.

Hudgins, J.W.; Krekling, T. \& Franceschi, V.R. 2003. Distribution of calcium oxalate crystals in the secondary phloem of conifers: a constitutive defense mechanism? New Phytologist 159: 677-690.

Jäger, K.; Fábián, A.; Tompa, G.; Deák, C.; Höhn, M.; Olmedilla, A.; Barnabás, B. \& Papp, I. 2010. New phenotypes of the droughttolerant cbp20 Arabidopsis thaliana mutant have changed epidermal morphology. Plant Biology 4: 34-45.

Jekel, P.A.; Hartmann, B.H. \& Beintema, J.J. 1991. The primary structure of hevamine, an enzyme with lysozyme/chitinase activity from Hevea brasiliensis latex. European Journal of Biochemistry 200: 123-130.

Johansen, D. 1940. Plant microtechnique. New York, McGray-Hill Book Company.

Kaul, R.B. 1977. The role of the multiple epidermis in foliar succulence of Peperomia Piperaceae). Botanical Gazette 138: 213-218.

Kerstiens, G. 1996. Cuticular water permeability and its physiological significance. Journal of Experimental Botany 47: 1813-1832.

Kimmel, J.R. \& Smith E.L. 1954. Crystalline papain. Part I. Preparation, specificity, and activation. Journal of Biological Chemistry 307: 515-31.

Köppen, W. 1948. Climatologia: versão para o espanhol de Pedro R. Hendrichs Pérez. México, Fondo de Cultura Econômica.

Lynn, K.R. \& Clevette-Radford, N.A. 1987a. Acid phosphatases from lattices of Euphorbiaceae. Phytochemistry 26: 655-657

Lynn, K.R. \& Clevette-Radford, N.A. 1987b. Biochemical properties of lattices from the Euphorbiaceae. Phytochemistry 26: 939-944.

Lin, Y.H. \& Lu, C.L. 1994. Latex trypsin inhibitors of sweet potato Ipomoea batatas Lam.). Botanical Bulletin of the Academy Sinensis 35: 153-159.

Macnish, A.J.; Irving, D.E.; Joyce, D.C.; Vithanage, V.; Wearing, A.H; Webb, R.I. \& Frost, R.L. 2003. Identification of intracellular calcium oxalate crystals in Chamelaucium uncinatum (Myrtaceae). Australian Journal of Botany 51: 565-72.

Mahlberg, P.G. 1993. Laticifers: an historical perspective. The Botanical Review 59: 1-23.

Marquis, R.J. 1984. Leaf herbivores decrease fitness of a tropical plant. Science 226: 537-539.
McLean, R.C. \& Cook, W.R.L. 1958. Plant Science Formulae. London, Macmillan \& Company Ltd.

Metcalfe, C.R. \& Chalk, L. 1988. Anatomy of the Dicotyledons. 2 ed. Oxford, Clarendon.

Molina, A.; Mena, M.; Carbonero, P. \& Garcia-Olmedo, F. 1997. Differential expression of pathogen-responsive genes encoding two types of glycine-rich proteins in barley. Plant Molecular Biology 33: 803-810.

Murray-Smith, C.; Brummitt, N.A.; Oliveira-Filho, A.T.; Bachman, S.; Moat, J.; Lughadha, E.M.N. \& Lucas, E.J. 2009. Plant diversity hotspots in the Atlantic coastal forests of Brazil. Conservation Biology 23: 151-163.

Myers, N.; Mittermeier, R.A.; Mittermeier, C.G.; Fonseca, G.A.B. \& Kent, J. 2000. Biodiversity hotspots for conservation priorities. Nature 403: 853-858.

Nascimento, M.T. \& Souza, J.S. 2003 . Tree growth, mortality and recruitment during a 6-yr period in a seasonally dry atlantic forest: effects of selective logging. Pp. 20-21 In: Ratter, J. \& Pennington, T. Tropical savannas \& seasonally dry forests: ecology, envirnment \& development. Abstracts of the tropical savannas \& seasonally dry forests conference. Edinburgo, The Royal Botanical Garden.

Okuda, T.; Suzuki, M.; Adachi, N.; Quah, E.S.; Hussein, N. \& Manokaran, N. 2003. Effect of selective logging on canopy and stand structure and tree species composition in a lowland dipterocarp forest in Peninsular Malaysia. Forest Ecology and Management 175: 297-320.

Pélissier, R.; Pascal, J.P.; Houllier, F. \& Laborde, H. 1998. Impact of selective logging on the dynamics of a low elevation dense moist evergreen forest in the Western Ghats South India). Forest Ecology and Management 105: 107-119.

RadamBrasil. 1983. Levantamento de recursos naturais. Rio de Janeiro, Ministério das Minas e Energia.

Rees, S.B. \& Harborne, J.B. 1985. The role of sesquiterpene lactones and phenolics in the chemical defense of the chicory plant. Phytochemistry 24: 2225-2231.

Riederer, M. \& Schreiber, L. 2001. Protecting against water loss: Analysis of the barrier properties of plant cuticles. Journal of Experimental Botany 52: 2023-2032.

Sagers, C.L. \& Coley, P.D. 1995. Benefits and costs of defense in a neotropical shrub. Ecology 76: 1835-1843.

Schägger, H. \& Von Jagow, G. 1987. Tricine-sodium dodecylsulfate polyacrylamide gel electrophoresis for the separation of proteins in the range from 1 to $100 \mathrm{kDa}$. Analytical Biochemistry 166: 368-379.

Sgarbieri, V.C.; Gupte, S.M.; Kramer, D.E. \& Whitaker, J.R. 1964. Ficus enzymes. Part I. Separation of proteolytic enzymes of Ficus carica and Ficus glabrata latices. Journal of Biological Chemistry 239: 2170-2177.

Schreiber, L. \& Riederer, M. 1996. Ecophysiology of cuticular transpiration: comparative investigation of cuticular water permeability of plant species from different habitats. Oecologia 107: 426-432.

Schreiber, L.; Skrabs, M.; Hartmann, K.; Diamantopoulos, K.; Simanova, E. \& Santrucek, J. 2001. Effect of humidity on cuticular water permeability of isolated cuticular membranes and leaf disks. Planta 214: 274-282

Schönherr, J. \& Riederer, M. 1989. Foliar penetration and accumulation of organic chemicals in plant cuticles. Reviews of Environmental Contamination and Toxicology 108: 1-70.

Silva, G.C. \& Nascimento, M.T. 2001. Fitossociologia de um remanescente de mata sobre tabuleiros no norte do estado do Rio de Janeiro (Mata do Carvão). Revista Brasileira de Botânica 24: 51-62.

Takahama, U. \& Oniki, T. 2000. Flavonoids and some other phenolics as substrates of peroxidase: Physiological Significance of the Redox Reactions. Journal of Plant Research 113: 301-309.

Takemori, N.K.; Bona, C. \& Alquini, Y. 2003. Anatomia comparada das folhas de espécies de Peperomia (Piperaceae): I. Ontogênese do tecido aqǘfero e dos estômatos. Acta Botanica Brasilica 173: 387-394.

Tenberge, K.B. 1992. Ultrastructure and development of the outer epidermal wall of spruce Picea abies needles. Canadian Journal of Botany 70: 1467-1487.

Tomar, R.; Kumar, R. \& Jagannadham, M.V. 2008. A stable serine protease, wrightin, from the latex of the plant Wrightia tinctoria Roxb. R. Br.: 
purification and biochemical properties. Journal of Agricultural and Food Chemistry 56: 1479-1487.

Van Parijs, J.; Broekaert, W.F.; Goldstein, I.J. \& Peumans, W.J. 1991. Hevein: An antifungal protein from rubber-tree Hevea brasiliensis latex. Planta 183: 258-264.

Veloso, H.P., Rangel Filho, A.L.R. \& Lima J.C.A. 1991. Classificação da vegetação brasileira adaptada a um sistema universal. Rio de Janeiro, Instituto Brasileiro de Geografia e Estatística IBGE.

Villela, D.M.; Nascimento, M.T.; Aragão, L.E.O.C. \& Gama, D.M. 2006. Effect of selective logging on forest structure and cycling in seasonally dry Brazilian forest. Journal of Biogeography 33: 506-516.
Volk, G.M.; Lynch-Holm, V.J.; Kostman, T.A.; Goss, L.J. \& Franceschi, V.R. 2002. The role of druse and raphide calcium oxalate crystals in tissue calcium regulation in Pistia stratiotes leaves. Plant Biology 4: 34-45.

Wititsuwannakul, D.; Chareonthiphakorn, N. \& Pace, M. 2002. Polyphenol oxidases from Hevea brasiliensis: purification and characterization. Phytochemistry 61: 115-121.

Whitmore, T.C. 1996. A review of some aspects of tropical rain forest seedling ecology with suggestions for further enquiry. Pp. 3-39. In: Swaine, M.D. (Ed.). The ecology of tropical forest seedlings. Paris, UNESCO and Parthenon Publishing Group. 